\title{
Forage yield, structural responses and chemical composition of spineless cactus Orelha de Elefante Mexicana in different water depths and irrigation frequencies
}

\author{
Juliana de Souza Pereira ${ }^{1}$ (D) Anderson Barbosa Cavalcante ${ }^{1}$ (i) Welson Lima Simões $^{2}$ (i) \\ Tadeu Vinhas Voltolini ${ }^{2^{*}}$ (D)
}

${ }^{1}$ Programa de Pós-graduação em Ciência Animal, Universidade Federal do Vale do São Francisco (Univasf), Petrolina, PE, Brasil. ${ }^{2}$ Embrapa Semiárido, 56302-970, Petrolina, PE, Brasil. E-mail: tadeu.voltolini@embrapa.br. "Corresponding author.

\begin{abstract}
The objective was to evaluate the effects of water depths and irrigation frequencies on structural responses, forage yield and chemical composition of spineless cactus Orelha de Elefante Mexicana (OEM) (Opuntia stricta (Haw.) Haw), in adensed crop system. The experimental design was randomized blocks, in subdivided plots (3x4) with 4 replicates. The water depths were (100\%, 75\%, 50\%, and 25\% of ETc - crop evapotranspiration) and three water application frequencies (7; 14 and 28 days between irrigations). There was interaction for water use efficiency (WUE) and plant dry mass. Increasing water depths reduced WUE for all irrigation frequencies and plant dry mass was lower for 7 days compared to 14 and 28 days in 25\% ETc. Greater water depths increased linearly the plant height and plant width. First and second order cladode length, second order cladode dry mass ( $\mathrm{kg}^{2}$, fresh mass yield (FMY) ( $\mathrm{kg} \mathrm{ha}^{-1}$ ) and dry mass yield (DMY) (kg ha $\left.\mathrm{a}^{-1}\right)$ had a quadratic response with the increase in water depth. The FMY and DMY increased up to 77\% and 75\% ETc, respectively. Irrigation frequency (28 days) promoted greater first order cladode length and cladode dry mass compared to 7 days. Cladode thickness in plant and basal cladode thickness were greater for 7 days compared to 28 days and 14 and 28 days, respectively, without influence on FMY and DMY. Irrigation frequencies from 7 to 28 days promotes similar forage production and water depths up to $77 \%$ ETc favors the forage yield for spineless cactus Orelha de Elefante Mexicana receiving supplemental irrigation.

Key words: Opuntia stricta (Haw.) Haw. forage, water supplementation.
\end{abstract}

Produção de forragem, respostas estruturais e composição química da palma-forrageira Orelha de Elefante Mexicana em diferentes lâminas e frequências de irrigação

\begin{abstract}
RESUMO: Objetivou-se avaliar os efeitos das lâminas e frequências de irrigação sobre as respostas estruturais, produção de forragem e composição química da palma-forrageira orelha de elefante mexicana (OEM) (Opuntia stricta (Haw.) Haw), em sistema adensado de cultivo. $O$ delineamento experimental foi em blocos casualizados, em parcelas subdivididas (3x4) com quatro repetições. As lâminas de água foram $100 \%, 75 \%, 50 \%$ e 25\% de ETc (evapotranspiração da cultura) e três frequências de aplicação de água (7; 14 e 28 dias entre as irrigações). Houve interação para eficiência de uso da água (EUA), massa seca de planta. A massa seca da planta aumentou com a aplicação de $64 \%$ da Etc na frequência de irrigação de 14 dias. O aumento nas lâminas reduziu a EUA para todas as frequências de irrigação e a massa seca de planta foi menor para 7 dias comparado com 14 e 28 dias, com o uso de $25 \%$ da ETc. As maiores lâminas de irrigação aumentaram linearmente a altura e a largura da planta. O comprimento dos cladódios da primeira e segunda ordens, a massa seca dos cladódios da segunda ordem, a produção de massa fresca (PMF) $\left(\mathrm{kg} \mathrm{ha}^{-1}\right)$ e a produção de massa seca (PMS) ( $\left.\mathrm{kg} \mathrm{ha} \mathrm{a}^{-1}\right)$ tiveram resposta quadrática com o aumento na lâmina de irrigação. O aumento na PMF e PMS ocorreu até $77 \%$ e 75\% da ETc, respectivamente. A frequência de irrigação (28 dias) promoveu maior comprimento e peso de cladódios da primeira ordem em comparação com sete dias. A espessura de cladódio e a espessura do cladódio basal foram maiores para sete dias comparado a 28 dias e 14 e 28 dias, respectivamente. A frequência de irrigação de 7 a 28 dias promove similar produção de forragem e a lâmina de irrigação até $77 \%$ da ETc favorece a produção da palma forrageira Orelha de Elefante Mexicana recebendo suplementação hídrica.
\end{abstract}

Palavras-chave: Opuntia stricta (Haw.) Haw, forragem, suplementação hídrica.

\section{INTRODUCTION}

Spineless cactus (Nopalea sp. and Opuntia sp.) has its vegetative growth related to rainfall, relative humidity, thermal amplitude, and water content in the soil (SCALISI et al., 2016). According to Nobel (2001), the growth of spineless cactus is climatically related to the occurrence of at least 400 to $800 \mathrm{~mm}$ of rain per year. In the Brazilian Semiarid many areas are restrictive to the cultivation of 
spineless cactus, such as very low rainfall and thermal amplitude (BEZERRA et al., 2015; LUCENA et al., 2016; SOUZA et al., 2018). In recent years, in several locations of Brazilian semi-arid, such as the Submedio of São Francisco, rainfall were very low and despite the high efficiency in the use of water, this low rainfall associated with high temperatures may reduce the forage yield and the longevity of spineless cactus production area.

The water supplementation for spineless cactus is represented by a strategical application of water via irrigation aiming to reduce the risks of loss of the crop and to increase the forage yield. Some studies have shown considerable increase in forage yield in spineless cactus systems using an additional supply of water strategically provided, especially for high density crop system, (REGO et al., 2014; QUEIROZ et al., 2015; ROCHA et al., 2017; PEREIRA et al., 2020), considering the effect of water in the soil decreases the restriction caused by climatic factors (SCALISI et al., 2016).

However, in drylands water is a scarce resource and it is fundamental for agricultural production. Thus, the production systems need to use this natural resource more efficiently. The establishment of adequate water depth and irrigation frequency is an important tool to maximize forage yield using less water.

QUEIROZ et al. (2015) reported the increase in water depth from $0 \%$ to $35 \%$ ETo (reference evapotranspiration) equivalent to 976 to $1,421 \mathrm{~mm}$ (380 days) did not influence the morphological traits and forage yield of spineless cactus Orelha de Elefante Mexicana (OEM) for a crop system with 15,625 plants ha-1, indicating 1,048 to $1,096 \mathrm{~mm}$ as enough to provide the productive responses to the crop.

Additionally, CASTRO et al. (2020) evaluated $0 \%$ to $75 \%$ of ETo equivalent to $680.9 \mathrm{~mm}$ (total rainfall) to $1,570 \mathrm{~mm}$ for Miúda and Gigante genotypes of spineless cactus and reported the greater fresh and dry mass yield (FMY, DMY) applying 40\% to $50 \%$ ETo, indicating the positive responses using supplemental irrigation, and also the possibility of adjusting irrigation management in order to save water.

The objective was to evaluate the effect of water depths and irrigation frequencies on structural responses, chemical composition and forage yield of spineless cactus Orelha de Elefante Mexicana.

\section{MATERIALS AND METHODS}

The field test was performed at Fazenda Agrocuraçá, in Curaçá-BA, Brazil, in an area already established with spineless cactus Orelha de Elefante Mexicana (OEM) (Opuntia stricta (Haw.) with three years of age. During the experimental period the rainfall was $366 \mathrm{~mm}$, ETo (reference evapotranspiration) was $2,288 \mathrm{~mm}$, the average temperature was $26{ }^{\circ} \mathrm{C}$, and the average relative humidity (RH) was $71 \%$.

The experimental design was a randomized block in subdivided plots $(3 \times 4)$ with 4 replicates, with four water depths and three water application frequencies, totaling 48 experimental units. The water depths evaluated were: $100 \%, 75 \%, 50 \%$ and $25 \%$ of ETc (culture evapotranspiration), based on the ETo accumulated during the interval between irrigations and $\mathrm{Kc}=0.52$ (crop coefficient) (QUEIROZ et al., 2016). The frequencies of water application studied were $7 ; 14$ and 28 days.

The irrigation was complementary to the rainfall, performed by dripping, using a dripper tube with a flat dripper, totaling $999.44 \mathrm{~mm}, 699.1$ $\mathrm{mm}, 499.72 \mathrm{~mm}$ and $249.86 \mathrm{~mm}$, respectively for $100 \%, 75 \%, 50 \%$ and $25 \%$ ETc, during the entire experimental period, which added to the precipitation totaled $1,365.4 \mathrm{~mm}, 1,065.6 \mathrm{~mm}, 865.7 \mathrm{~mm}$ and $615.86 \mathrm{~mm}$, for $100 \%, 75 \%, 50 \%$ and $25 \% \mathrm{ETc}$, respectively.

The planting density was 50,000 plants $\mathrm{ha}^{-1}$, corresponding to $2,0 \mathrm{~m} \times 0,10 \mathrm{~m}$ planting spacing. The soil in the area is classified as Vertisol and the results of the analysis for a 0 to $20 \mathrm{~cm}$ layer were: electrical conductivity $(\mathrm{EC})=0.68 \mathrm{mS} \mathrm{cm}{ }^{-1} ; \mathrm{pH}=4.6 ; \mathrm{P}=8.27$ $\mathrm{mg} \mathrm{dm}{ }^{-3} ; \mathrm{K}=0.09 \mathrm{cmol}_{\mathrm{c}} \mathrm{dm}^{-3} ; \mathrm{Na}=0.23 \mathrm{cmol}_{\mathrm{c}} \mathrm{dm}^{-3}$; $\mathrm{Ca}=3.6 \mathrm{cmol} \mathrm{dm}^{-3} ; \mathrm{Mg}=2.6 \mathrm{cmol}_{\mathrm{c}} \mathrm{dm}^{-3} ; \mathrm{H}+\mathrm{Al}=$ $4.8 \mathrm{cmol}_{\mathrm{c}} \mathrm{dm}^{-3}$; sum of bases $(\mathrm{SB})=6.50 \mathrm{cmol}_{\mathrm{c}} \mathrm{dm}^{-3}$; cation exchange capacity $(\mathrm{CEC})=11.3 \mathrm{cmol}_{\mathrm{c}} \mathrm{dm}^{-3}$. For the 20 to $40 \mathrm{~cm}$ layer: $\mathrm{EC}=0.38 \mathrm{mS} \mathrm{cm}^{-1} ; \mathrm{pH}=$ $4.8 ; \mathrm{P}=4.16 \mathrm{mg} \mathrm{dm}^{-3} ; \mathrm{K}=0.05 \mathrm{cmol}_{\mathrm{c}} \mathrm{dm}^{-3} ; \mathrm{Na}=0.31$ $\mathrm{cmol} \mathrm{dm}^{-3} ; \mathrm{Ca}=3.2 \mathrm{cmol} \mathrm{dm}^{-3} ; \mathrm{Mg}^{\mathrm{c}}=2.0 \mathrm{cmol} \mathrm{dm}^{-3}$; $\mathrm{H}+\stackrel{\mathrm{c}}{\mathrm{A}}=4.6 \mathrm{cmol}_{\mathrm{c}} \mathrm{dm}^{-3} ; \mathrm{SB}=5.60 \mathrm{cmol}_{\mathrm{c}} \mathrm{dm}^{-3}$; $\mathrm{CEC}$ $=10.1 \mathrm{cmol}_{\mathrm{c}} \mathrm{dm}^{-3}$.

Morphological traits (plant height and width, number, size, weight, and CAI were measured in three plants of the useful area in all cladodes of each plant. Plant height was evaluated using a tape, measuring from the ground level up to the end of the highest cladode. The plant width was also determined using a tape, evaluating the plant from a side to side. All cladodes in each plant were evaluated, counting the total number per plant and per order (first, second, third and fourth orders). Cladodes of first order were above basal cladode, and second, third and fourth were above first, second and third cladode orders, respectively. 
Cladodes were individually measured for length and width using a tape to subsequently determine the CAI. Cladode thickness was evaluated using a caliper. The CAI was calculated as follow: (cladode area $\left(\mathrm{cm}^{2}\right) \times$ number of cladodes per plant) $\div$ $10,000 \div(\mathrm{E} 1 \mathrm{x} \mathrm{E} 2)$, considering 10,000 as conversion factor from $\mathrm{cm}^{2}$ to $\mathrm{m}^{2}$ and $\mathrm{E} 1 \mathrm{x} \mathrm{E} 2$, the spacing between rows and between plants, respectively (PINHEIRO et al., 2014).

Fresh mass yield (FMY) ( $\left.\mathrm{kg} \mathrm{ha}^{-1}\right)$ and dry mass yield (DMY) $\left(\mathrm{kg} \mathrm{ha}^{-1}\right)$ were estimated by cutting and weighing three plants per plot (15 plants per treatment), multiplying by the number of plants ha $^{-1}$. Plant cut was performed maintaining the basal cladode and the forage material was weighted to determine plant dry mass $\left(\mathrm{kg} \mathrm{plant}^{-1}\right)$. Additionally, all cladodes in each plant were weighed to determine cladode dry mass per order $(\mathrm{kg})$.

Water use efficiency (WUE) was estimated considering the rainfall volume plus the volume of water applied by irrigation along 12 months, and the dry mass yield $\left(\mathrm{kg} \mathrm{ha}^{-1}\right)$.

Samples were dehydrated in a forced ventilation oven at $55{ }^{\circ} \mathrm{C}$ until constant weight and ground through a $1 \mathrm{~mm}$ screen in a mill. The dry matter (DM, method 967.03), ash (method 642.05), crude protein (CP, method 981.10) were determined according to AOAC, (1990), neutral detergent fiber (NDF), and in vitro dry matter digestibility (IVDMD) according to Van Soest et al. (1991), with approval by the Ethics Committee on the Use of Animals (CEUA) of Embrapa Semiárido (Protocol 10/2017). The sampling for chemical and IVDMD analysis was performed considering all cladode orders.

The monitoring of soil moisture was performed immediately before and after irrigation events, using the TDR (Time Domain Reflectometry) equipment and it was measured at the 0-20 cm layer, during August and September 2018, lasting 28 days, in which each assessment was weekly (Table 1).

The data were submitted to analysis of variance and Tukey test. A regression analysis was performed for water depths. The software used was the Statistical Analysis System - SAS (2009), considering as significant probability values below $5 \%(\mathrm{P}<0.05)$.

\section{RESULTS AND DISCUSSION}

There was interaction (water depths and irrigation frequency) on plant dry mass, first order cladode dry mass and WUE. There was no interaction on plant height, plant width, total number of cladodes, CAI, cladode length, width and thickness, considering the average in plant and per order. Forage yield, chemical composition and IVDMD of spineless cactus were also not influenced by interaction (Table 2).

The most frequent irrigation interval (7 days) promoted greater WUE compared to 14 and 28 days for $25 \%$ ETc, while for $100 \%$ ETc the irrigation frequency of 7 days reduced WUE compared to 14 and 28 days (Table 2). These results are attributed to the water availability in the soil, which the lower water depth $(25 \%)$ in the irrigation interval of 7 days promoted $7 \%$ to $26 \%$ of soil humidity, while for 28 days it ranged from $1 \%$ to $27 \%$ (Table 1 ), influencing the physiological responses of plant. The water deficit promotes stomatal closure and reduces $\mathrm{CO}_{2}$ to photosynthesis (TAIZ et al., 2017). The high soil humidity for $100 \%$ ETc and 7 days of irrigation interval reduced WUE, demonstrating spineless cactus does not have all this water requirement, indicating the amount of water

Table 1 - Soil humidity (\%) with spineless cactus Orelha de Elefante Mexicana (Opuntia stricta (Haw.) Haw) in different water depths and irrigation frequencies, before and after irrigation, in Curaça, BA.

\begin{tabular}{|c|c|c|c|c|c|c|c|c|c|c|}
\hline \multirow{3}{*}{ Frequency (days) } & \multicolumn{10}{|c|}{ 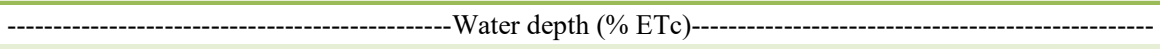 } \\
\hline & \multicolumn{2}{|c|}{-------25\%------- } & \multicolumn{2}{|c|}{-------50\%-------- } & \multicolumn{2}{|c|}{----------75\%o-------- } & \multicolumn{2}{|c|}{--------100\%------- } & \multicolumn{2}{|c|}{-----Average-------- } \\
\hline & BI & AI & BI & AI & BI & AI & BI & AI & BI & AI \\
\hline 7 & 9 & 16 & 10 & 18 & 11 & 23 & 13 & 25 & 10.7 & 20.5 \\
\hline 14 & 6 & 19 & 8 & 22 & 8 & 23 & 9 & 26 & 7.75 & 22.5 \\
\hline 28 & 1 & 27 & 2 & 28 & 3 & 28 & 4 & 28 & 2.5 & 27.7 \\
\hline Average & 5.3 & 20.7 & 6.7 & 22.7 & 7.3 & 24.7 & 8.7 & 26.3 & & \\
\hline
\end{tabular}

$\mathrm{ETc}=$ Evapotranspiration of culture $\mathrm{BI}=$ before irrigation. $\mathrm{AI}=$ after irrigation. 
Table 2 - Interaction of water depths and irrigation frequency for plant dry mass, first order cladode dry mass, and water use efficiency of spineless cactus Orelha de Elefante Mexicana.

\begin{tabular}{|c|c|c|c|c|}
\hline \multirow[t]{2}{*}{ Irrigation frequency } & \multicolumn{4}{|c|}{ 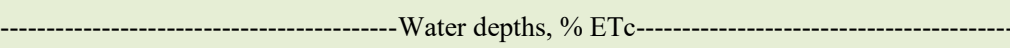 } \\
\hline & $25 \%$ & $50 \%$ & $75 \%$ & $100 \%$ \\
\hline \multicolumn{5}{|c|}{ 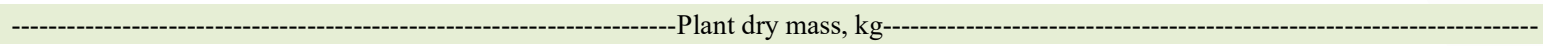 } \\
\hline 7 days & $0.338 \mathrm{~B}$ & $0.448 \mathrm{~A}$ & $0.358 \mathrm{~B}$ & 0.430 \\
\hline 14 days & $0.442 \mathrm{~A}$ & $0.350 \mathrm{AB}$ & $0.444 \mathrm{AB}$ & 0.510 \\
\hline 28 days & $0.430 \mathrm{AB}$ & $0.346 \mathrm{~B}$ & $0.468 \mathrm{~A}$ & 0.420 \\
\hline \multicolumn{5}{|c|}{ - } \\
\hline 7 days & $0.142 \mathrm{~B}$ & 0.190 & 0.152 & 0.194 \\
\hline 14 days & $0.218 \mathrm{~A}$ & 0.188 & 0.208 & 0.242 \\
\hline 28 days & $0.274 \mathrm{~A}$ & 0.178 & 0.202 & 0.204 \\
\hline \multicolumn{5}{|c|}{ 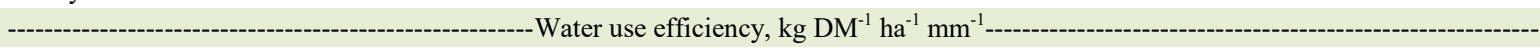 } \\
\hline 7 days & $29.08 \mathrm{~A}$ & 26.63 & 24.40 & $17.41 \mathrm{~B}$ \\
\hline 14 days & $15.82 \mathrm{~B}$ & 28.37 & 21.06 & $26.89 \mathrm{~A}$ \\
\hline 28 days & $15.43 \mathrm{~B}$ & 28.02 & 21.70 & $24.22 \mathrm{~A}$ \\
\hline
\end{tabular}

In the row, average followed by different upper case differs statistically by Tukey test $(\mathrm{P}<0.05)$. ETc $=$ culture evapotranspiration.

applied can be reduced, increasing its efficiency (Table 3). This result can be seen in table 3, the increase in water depth reduced linearly the WUE for all irrigation frequency evaluated.

The irrigation interval of 7 days promoted lower plant dry mass compared to 14 days, when it was applied $25 \%$ ETc and compared to 28 days applying $75 \%$ ETc. However, applying 50\% ETc, the irrigation frequency of 7 days provided greater plant dry mass in relation to 28 days. The most frequent irrigation interval (7 days) also promoted lower first order cladode dry mass compared to 14 and 28 days
(Table 3), which may be associated with the water deficit or excess promote stomatal closure, as they become stressors factors, reducing $\mathrm{CO}_{2}$ absorption and photoassimilates production as sugars and organic acids, influencing the plant development (SILVA et al., 2015; TAIZ et al., 2017).

This negative factor of the lack or excess of water for the plant is also observed that increasing water depth promoted a quadratic response in plant dry mass and in first order cladode dry mass, respectively for intermediate (14 days) and longest irrigation intervals (28 days), respectively

Table 3 - Plant dry mass, first order cladode dry mass and water use efficiency of spineless cactus Orelha de Elefante Mexicana in different irrigation frequency.

\begin{tabular}{|c|c|c|}
\hline Irrigation frequency & Equation & $\mathrm{R}^{2}$ \\
\hline \multicolumn{3}{|c|}{ 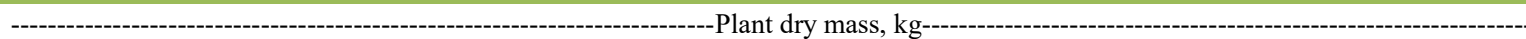 } \\
\hline 7 days & 0.398 & - \\
\hline 14 days & $y=-7 E-05 x^{2}+0.009 x+0.18$ & 0.68 \\
\hline 28 days & 0.417 & - \\
\hline \multicolumn{3}{|c|}{ 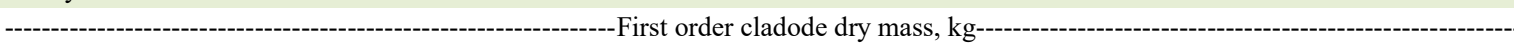 } \\
\hline 7 days & 0.169 & - \\
\hline 14 days & 0.214 & - \\
\hline 28 days & $y=2 E-05 x^{2}-0.001 x+0.1988$ & 0.90 \\
\hline \multicolumn{3}{|c|}{ Water use efficiency, $\mathrm{kg} \mathrm{DM}^{-1} \mathrm{ha}^{-1} \mathrm{~mm}^{-1}-$} \\
\hline 7 days & $y=-0.149 x+33.699$ & 0.92 \\
\hline 14 days & $y=-0.1739 x+33.904$ & 0.95 \\
\hline 28 days & $y=-0.1611 x+32.412$ & 0.97 \\
\hline
\end{tabular}

Ciência Rural, v.51, n.5, 2021. 
(Table 3). Greater plant dry mass $(0.47 \mathrm{~kg})$ was observed applying 64\% ETc and higher first order cladode dry mass $(0.19 \mathrm{~kg})$ was found with $25 \% \mathrm{ETc}$.

Plant width and plant height increased linearly with greater water depths (Table 2). CASTRO et al. (2020) also observed an increase in plant height for Miúda and Gigante genotypes increasing water depth in the supplemental irrigation, reporting $29.26 \%$ ETo promoted maximum plant height at 360 days after planting.

Water depths or irrigation frequency did not affect the number of cladodes and cladode width in plant and per order. On average, total number of cladodes in plant and per order (first, second and third orders) was $11.20 ; 4.3 ; 5.8$ and 0.1 , respectively. Cladode width was on average, $19.0 ; 20.8 ; 18.2 ; 19.0$ and $1.6 \mathrm{~cm}$, respectively, considering the average in plant, basal cladode, and cladodes from first, second, and third orders.

Greater water depths increased and first and second orders cladode length up to $72 \%$ and $78 \%$ ETc, reaching $0.19 \mathrm{~cm}$ to $0.28 \mathrm{~cm}$, respectively (Table 4). Cladode thickness and CAI was not influenced by water depths. The thickness of cladodes was on average $1.5 \mathrm{~cm}$, considering all cladodes in plant, and $4.1 ; 1.5 ; 1.1$ and $0.1 \mathrm{~cm}$ for basal cladode and first, second and third cladodes orders, respectively.

First order cladode dry mass increased linearly, considering the water depths (Table 4). The highest FMY $\left(314,845 \mathrm{~kg} \mathrm{ha}^{-1}\right)$ and DMY $(23,661$ $\mathrm{kg} \mathrm{ha}^{-1}$ ) was observed when it was applied $77 \%$ and $75 \%$ ETc, respectively, demonstrating the additional water supply by supplemental irrigation promotes structural changes on plant, especially on first cladode order, increasing plant height and width and promoting greater forage yield.

First order cladode length and cladode dry mass were lower for 7 days compared to 28 days, without difference for both compared to 14 days (Table 5). The most frequent irrigation interval (7 days) promoted $10.7 \%$ to $20.5 \%$ of soil humidity before and after irrigation, while the irrigation interval of 28 days provided $2.5 \%$ to $27.7 \%$ of soil humidity (Table 1), both strategies allow a similar productive performance.

Average cladode thickness in the plant and thickness of basal cladode were greater for 7 days compared to 28 days (average cladode thickness) and 14 or 28 days for basal cladode thickness (Table 3 ).

Irrigation frequency did not influence FMY and DMY. Pereira et al. (2015) also did not observe differences on growth variables for IPA Sertânia, Miúda and Orelha de Elefante Mexicana genotypes, evaluating three irrigation intervals $(7,14$ and 28 days).

According to SCALISI et al. (2015) the spineless cactus is able to present growth at low hydration levels and the cladode growth is very responsive to rehydration, storing water in its parenchyma and releases to chlorenchyma to perform many physiological activities even for long irrigation frequency.

Total number of cladodes and CAI are indicative of similar plant growth considering all irrigation frequencies. CORTÁZAR \& NOBEL (1991) reported the CAI represents the photosynthesis capacity of the plant and is related to the spineless cactus growth. The CAI observed in this research was 1.9 , very close to the 2.0 to 2.5 considered as the values to maximize cactus yield.

Crude protein, NDF, ash and IVDMD was not influenced by water depths and irrigation frequencies, presenting $7.77 \%, 6.20 \%, 15.83 \%$, $20.78 \%$ and $79.80 \%$ for DM, CP, ash, NDF and IVDMD, respectively, due to the similar maturity stage of cladodes.

Table 4 - Structural responses and forage yield of spineless cactus Orelha de Elefante Mexicana (Opuntia stricta (Haw.) Haw) in different water depths, and harvested 12 months after regrowth, in Curacá-BA

\begin{tabular}{lcc}
\hline Variable & \multicolumn{1}{c}{ Equation } \\
\hline Plant height, $\mathrm{m}$ & $\mathrm{y}=0.079 \mathrm{x}+61.392$ & $\mathrm{R}^{2}$ \\
Plant width, $\mathrm{m}$ & $\mathrm{y}=0.0856 \mathrm{x}+69.984$ & 0.95 \\
First order cladode length, $\mathrm{cm}$ & $\mathrm{y}=-0.0008 \mathrm{x}^{2}+0.1454 \mathrm{x}+20.565$ & 0.93 \\
\hline Second order cladode length, $\mathrm{cm}$ & $\mathrm{y}=-0.0009 \mathrm{x}^{2}+0.1404 \mathrm{x}+22.496$ & 0.99 \\
FMY, $\mathrm{kg} \mathrm{ha}^{-1}$ & $\mathrm{y}=-31.625 \mathrm{x}^{2}+4904.2 \mathrm{x}+124717$ & 0.98 \\
DMY, $\mathrm{kg} \mathrm{ha}^{-1}$ & $\mathrm{y}=-2.3386 \mathrm{x}^{2}+351.5 \mathrm{x}+10454$ & 0.99 \\
\hline
\end{tabular}

Ciência Rural, v.51, n.5, 2021. 
Table 5 - Structural responses of spineless cactus Orelha de Elefante Mexicana (Opuntia stricta (Haw.) Haw) in different irrigation frequency and harvested 12 months after regrowth, in Curaçá-BA.

\begin{tabular}{|c|c|c|c|}
\hline & ---------- & on frequenc & -------- \\
\hline Variable & 7 & 14 & 28 \\
\hline First order cladode length, $\mathrm{m}$ & $0.248 \mathrm{~B}$ & $0.260 \mathrm{AB}$ & $0.262 \mathrm{~A}$ \\
\hline Cladode thickness, $\mathrm{cm}$ & $1.58 \mathrm{~A}$ & $1.51 \mathrm{AB}$ & $1.44 \mathrm{~B}$ \\
\hline Basal cladode thickness, $\mathrm{cm}$ & $4.52 \mathrm{~A}$ & $4.08 \mathrm{~B}$ & $3.72 \mathrm{~B}$ \\
\hline
\end{tabular}

In the line, average followed by different upper case differs statistically by Tukey test $(\mathrm{P}<0.05)$.

\section{CONCLUSION}

Water depths up to $77 \%$ of crop evapotranspiration increases forage yield, and irrigation frequency from 7 to 28 days can be adopted for spineless cactus Orelha de Elefante Mexicana.

\section{ACKNOWLEDGEMENTS}

This study was financed in part by the the Coordenação de Aperfeiçoamento de Pessoal de Nível Superior Brasil (CAPES) - Finance code 001. As well as with the support of Embrapa Semiárido through research aid $\left(\mathrm{n}^{\circ}\right.$ 02.16.04.28.00.07).

\section{DECLARATION OF CONFLICT OF INTERESTS}

The authors declare that there is no conflict of interest. The funding entities had no influence on the study design; nor in the collection, analysis or interpretation of the data; in the writing of the manuscript, nor in the decision to publish the results.

\section{AUTHORS' CONTRIBUTIONS}

All authors contributed equally for the conception and writing of the manuscript. All authors critically revised the manuscript and approved of the final version.

\section{BIOETHICS AND BIOSSECURITY COMMITTEE APPROVAL}

This research was approved by the Ethics Committee on the Use of Animals (CEUA) of Embrapa Semiárido (Protocol 10/2017).

\section{REFERENCES}

AOAC - Association of Official Analitical Chemists. Official Methods of Analysis. 15th ed. Arlington: AOAC, 1990.

BEZERRA, S. A. F., et al. Gross water demand of forage cactus on future scenarios of climate change in the State of Pernambuco. Revista Brasileira de Geografia Física. v.8, n.6, p.1628-1643,
2015. Available from: <https://periodicos.ufpe.br/revistas/rbgfe/ article/view/233666>. Accessed: Apr. 2, 2020. doi: 10.26848/rbgf. v8.6.p1628-1643.

CASTRO, I. N., et al. Desempenho agronômico e eficiência de uso da água em cultivares de palma forrageira irrigada. Revista Caatinga, v.33, n.2, p.529-540, 2020. Available from: <https:// periodicos.ufersa.edu.br/index.php/caatinga/article/view/9022>. Accessed: Sep. 14, 2020. doi: 10.1590/1983-21252020v33n225rc.

LUCENA, D. B., et al. Aptidão e zoneamento agroclimático da palma forrageira para o estado do Piauí. Revista Brasileira de Agricultura Irrigada. v.10, n.4, p.809-819, 2016. Available from: <http://www.inovagri.org.br/revista/index.php/rbai/article/ view/450>. Accessed: Apr. 2, 2020. doi: 10.7127/rbai.v10n400450.

CORTÁZAR, V. G.; NOBEL, P. S. Prediction and measurement of high annual productivity for Opuntia ficus-indica. Agricultural and Forest Meteorology. v.56, p261-272, 1991. Available from: <https://www.sciencedirect.com/science/ article/pii/0168192391900958>. Accessed: Apr. 2, 2020. doi: 10.1016/0168-1923(91)90095-8.

NOBEL, P. S. Biologia ambiental. In: BARBERA, G.; et al. (Eds.) Agroecologia, cultivos e usos da palma forrageira. Paraíba: SEBRAE/PB, p.36-57. 2001.

PEREIRA, J. S., et al. Morphological and yield responses of spineless cactus Orelha de Elefante Mexicana under different cutting intensities. Revista Brasileira de Saúde e Produção Animal, v.21, 2020. Available from: <https://www.scielo.br/pdf/ rbspa/v21/1519-9940-rbspa-21-e2121142020.pdf>. Accessed: Sep. 14, 2020. doi: 10.1590/S1519-99402121142020.

PEREIRA, P. C. et al. Morfogênese da palma forrageira irrigada por gotejamento. Revista Caatinga, v.28, n.3, p.184-195, 2015. Available from: <https://www.scielo.br/scielo.php?pid=S198321 $252015000300184 \&$ script $=$ sci_arttext\&tlng=pt $>$. Accessed: Sep. 14, 2020. doi: 10.1590/1983-21252015v28n321rc.

PINHEIRO, K. M., et al. Correlações do índice de área do cladódio com características morfogênicas e produtivas da palma forrageira. Pesquisa Agropecuária Brasileira, v.49, n.12, p.939-947. 2014. Available from: $<$ https://www.scielo.br/scielo.php?pid=S0100204X2014001200939\&script $=$ sci_arttext\&tlng=pt $>$. Accessed: Sep. 14, 2020. doi: 10.1590/S0100-204X2014001200004.

QUEIROZ, M. G., et al. Características morfofisiológicas e produtividade da palma forrageira em diferentes lâminas 
de irrigação. Revista Brasileira de Engenharia Agrícola e Ambiental, v.19, n.10, p.931-938, 2015. Available from: $<$ http://www.scielo.br/scielo.php?pid=S1415436620150010009 31\&script $=$ sci_abstract\&tlng $=$ pt $>$. Accessed: Apr. 2, 2020. doi: 10.1590/1807-1929/agriambi.v19n10p931-938.

QUEIROZ, M. G., et al. Relações hídrico-econômicas da palma forrageira cultivada em ambiente semiárido. Irriga, v.1, n.01, p.141-141. 2016. Available from: <http://irriga.fca.unesp.br/ index.php/irriga/article/view/1814>. Accessed: Sep. 14, 2020. doi: 10.15809/irriga.2016v1n01p141-154.

REGO, M. M. T., et al. Morphology and biomass yield of irrigated prickly-pear cactus cv. Miúda under doses of organic fertilizer and cutting intensities. Revista Científica de Produção Animal, v.16, n.2, p.118-130, 2014. Available from: <https://www.alice.cnptia. embrapa.br/handle/doc/1029952>. Accessed: Sep. 14, 2020. doi: 10.15528/2176-4158/rcpa.v16n2p118-130.

ROCHA, R. S., et al. Características produtivas e estruturais de genótipos de palma forrageira irrigada em diferentes intervalos de corte. Archivos de Zootecnia, v.66, n.255, p.363371, 2017. Available from: <https://dialnet.unirioja.es/servlet/ articulo? codigo $=6495638>$. Accessed: Mar. 29, 2020. doi: 10.21071/az.v66i255.2512.

SILVA, F. G. et al. Trocas gasosas e fluorescência da clorofila em plantas de berinjela sob lâminas de irrigação. Revista Brasileira de
Engenharia Agrícola e Ambiental, v.19, n.10, p.946-952, 2015. Available from: <http://www.agriambi.com.br/revista/v19n10/ v19n10a06.pdf>. Accessed: Sep. 22, 2020. doi: 10.1590/18071929/agriambi.v19n10p946-952.

SAS. Statistical Analysis System. (2009). User's guide: statistics. (Version 9.0). Cary, NC: SAS Inst Inc.

SCALISI, A., et al. Cladode growth dynamics in Opuntia ficusindica under drought. Environmental and Experimental Botany, v.122, p.158-167, 2016. Available from: <https://www. sciencedirect.com/science/article/abs/pii/S0098847215300241>. Accessed: Apr. 2, 2020. doi: 10.1016/j.envexpbot.2015.10.003

SOUZA, D. C. F., et al. Zoneamento agroclimático da palma forrageira (Opuntia sp) para o estado de Sergipe. Revista Brasileira de Agricultura Irrigada. v.12, n.1, p.2338-2347., 2018. Available from: <http://www.inovagri.org.br/revista/index.php/rbai/article/ view/715>. Accessed: Apr. 2, 2020. doi: 10.7127/rbai.v12n100715.

TAIZ, L.; et al. Fisiologia e desenvolvimento vegetal. 6.ed. Porto Alegre: Artmed, 2017. 858p.

VAN SOEST, P. J., et al. Methods for dietary fiber, neutral detergent fiber, and non-starch polysaccharides in relation to animal nutrition. Journal of Dairy Science, v.74, p.3583-3597, 1991. Available from: $<$ https://www.ncbi.nlm.nih.gov/pubmed/1660498>. Accessed: Apr. 2, 2020. doi: 10.3168/jds.S0022-0302(91)78551-2. 